\title{
Growing season length as a key factor of cumulative net ecosystem exchange over the pine forest ecosystems in Europe**
}

\author{
Alina Danielewska ${ }^{1 *}$, Marek Urbaniak ${ }^{1}$, and Janusz Olejnik $k^{1,2}$ \\ ${ }^{1}$ Department of Meteorology, Poznań University of Life Sciences, Piątkowska 94, 60-649 Poznań, Poland \\ ${ }^{2}$ Department of Matter and Energy Fluxes, Global Change Research Center, AS CR, v.v.i. Belidla 986/4a, 603 00 Brno, Czech Republic
}

Received February 9, 2015; accepted March 19, 2015

\begin{abstract}
The Scots pine is one of the most important species in European and Asian forests. Due to a widespread occurrence of pine forests, their significance in the energy and mass exchange between the Earth surface and the atmosphere is also important, particularly in the context of climate change and greenhouse gases balance. The aim of this work is to present the relationship between the average annual net ecosystem productivity and growing season length, latitude and air temperature (tay) over Europe. Therefore, $\mathrm{CO}_{2}$ flux measurement data from eight European pine dominated forests were used. The observations suggest that there is a correlation between the intensity of $\mathrm{CO}_{2}$ uptake or emission by a forest stand and the above mentioned parameters. Based on the obtained results, all of the selected pine forest stands were $\mathrm{CO}_{2}$ sinks, except a site in northern Finland. The carbon dioxide uptake increased proportionally with the increase of growing season length $\left(9.212 \mathrm{~g} \mathrm{C} \mathrm{m}^{-2} \mathrm{y}^{-1}\right.$ per day of growing season, $\mathrm{R}^{2}=0.53, \mathrm{p}=0.0399$ ). This dependency showed stronger correlation and higher statistical significance than both relationships between annual net ecosystem productivity and air temperature $\left(\mathrm{R}^{2}=0.39, \mathrm{p}=0.096\right)$ and annual net ecosystem productivity and latitude $\left(\mathrm{R}^{2}=0.47, \mathrm{p}=0.058\right)$. The $\mathrm{CO}_{2}$ emission surpassed assimilation in winter, early spring and late autumn. Moreover, the appearance of late, cold spring and early winter, reduced annual net ecosystem productivity. Therefore, the growing season length can be considered as one of the main factor affecting the annual carbon budget of pine forests.

$\mathrm{K}$ e y w o r d s: forest, carbon dioxide, eddy covariance, growing season length
\end{abstract}

\section{INTRODUCTION}

In the last decade the atmospheric $\mathrm{CO}_{2}$ concentration increased about $1.5 \mathrm{ppm}$ per year (NOAA, 2014). From the point of view of climate change, the increase in $\mathrm{CO}_{2}$ in

*Corresponding author e-mail: alinkadanie@poczta.onet.pl

**This work was supported by the State Forest National Holding and European Community Sixth Framework Programme project CarboEurope-IP (contract No. GOCE-CT-2004-505572) from Tuczno site. the atmosphere is an unfavourable phenomenon, even if for plants growth and productivity stimulation can occur (Keenan et al., 2014). In this context, special attention should be focused on forest ecosystems and their abilities to accumulate a significant amount of $\mathrm{CO}_{2}$ from the atmosphere, up to $610 \mathrm{~g} \mathrm{C} \mathrm{m}^{-2} \mathrm{y}^{-1}$ (Luyssaert et al., 2010). However, the amount of uptaken carbon (C) is strongly dependent on weather conditions (air temperature, precipitation, radiation) (Niu et al., 2012), air quality (concentrations of $\mathrm{CO}_{2}, \mathrm{O}_{3}$ and $\mathrm{N}$ compounds) (Ciais et al., 2010), tree species, soil type (Lal, 2005) and forest management practices (Jandl et al., 2007).

The net ecosystem production (NEP), corresponding to the net amount of carbon dioxide exchanged between the forest ecosystem and the atmosphere, is the balance between the ecosystem respiration $\left(\mathrm{R}_{\mathrm{ECO}}\right)$ and overall uptake in the photosynthesis process (gross ecosystem production-GEP). Therefore, to better understand the causes of the changes in the NEP fluxes over time, with respect to the meteorological conditions at particular sites, the authors attempt to determine the time frame of the growing season for each of the selected sites. In literature there are many definitions of the growing season or so-called uptake period (Barr et al., 2009). For example, the growing season could be defined as a period during the year in which the gross ecosystem production (GEP) fluxes are at least 15\% of the maximum annual rate (Coursolle et al., 2012). Because of the lack of a standard criterion for determining the starting and the ending date of the growing season, the authors proposed here their own method of determining the growing season time frame.

(C) 2015 Institute of Agrophysics, Polish Academy of Sciences 
Research related to the influence of growing season length (GSL) on the annual (NEPy) fluxes variability were carried out both across Europe (Churkina et al., 2005) and locally - in such forest ecosystems as: boreal Scots Pine in Finland (Suni et al., 2003), boreal Trembling Aspen (Populus tremuloides) in Canada (Chen et al., 1999) we measured $\mathrm{CO}_{2}$ fluxes using the eddy covariance technique above an old aspen (OA or broadleaf forest in the east of the USA (Dragoni et al., 2011). Despite the fact that the GSL for the above ecosystems was assigned by different methods, a positive linear correlation between these two quantities was observed - the GSL prolongation increased the NEP flux values. However, it should also be mentioned, that under some local conditions, which are characteristic in particular locations, the relation between GSL and NEP may show an opposite correlation, like an subalpine coniferous forest ecosystems (Hu et al., 2010). The authors explain this phenomenon of water limitation in the subalpine ecosystem, resulting from the early snowmelt and low summer precipitation.

Taking into consideration the location of forest ecosystems on Earth, tropical, temperate and boreal forest ecosystems may be distinguished. Temperate forest ecosystems occur between 40 and $60^{\circ}$ latitude, both in the northern and the southern hemisphere. In general, meteorological conditions in these latitudes can be characterised by: the average air temperature in summer months of $18-20^{\circ} \mathrm{C}$, around $3-5^{\circ} \mathrm{C}$ in winter months and the annual precipitation of about $600 \mathrm{~mm}$ (Chapin III et al., 2011). In case of boreal forests, which are located between 50 and $70^{\circ}$ latitude, local climate is significantly diversified by the influence of the continental and marine air masses. In boreal forest, winter circulation is dominated by polar air masses, and in summer by temperate air masses, resulting in very cold winters $\left(<-60^{\circ} \mathrm{C}\right.$ temperature minima) and warm summers $\left(>30^{\circ} \mathrm{C}\right.$ temperature maxima). The annual precipitation totals ranges from 300 to more than $1000 \mathrm{~mm}$, depending on the distance to the nearest ocean (Schulze et al., 2009). Forest ecosystems in Europe, with respect of species composition, consist of pine to the extent of 50\% (Pinus spp.). Because of described diversification of meteorological conditions in boreal and temperate forests, significant differences in the net ecosystem production can be expected. On the other hand, some species, like the Scots pine trees are well adapted to a wide range of meteorological conditions. Pine forests are spreading from Spain to the north of Finland, therefore, they are a relevant example for analyzing meteorological conditions influence on the annual NEP in forest across Europe, over a long period of time.

As nowadays longer data series and additional sites were available, compared to previous studies Luyssaert et al. (2007), we hypothesize that the growing season length could exhibit even stronger influence on the annual carbon uptake of pine-dominated European forest stands as reported in previous works.

\section{MATERIALS AND METHODS}

The analysis conducted in this study, involved pinedominated forest stands only (Pinus sylvestris or Pinus pinaster) since pine is the most widespread tree genus in the northern hemisphere (Ceulemans et al., 2003). In all selected sites the net $\mathrm{CO}_{2}$ fluxes were measured by the eddy covariance (EC) technique.

To put it simply, the theory of the eddy covariance method assumes, that in the case of a notionally separated volume (eg a portion of air above a canopy), the molecules of a gas, such as $\mathrm{CO}_{2}$, move constantly in both directions (eddies are created), and that at the same time the concentration of the gas in that volume remains unchanged. In these conditions one is dealing with a stationary flow, which means that it does not change in time and is equal at different heights inside the analyzed volume. If we assume that this condition is met we can then measure the exchange between the atmosphere and the surface of interest, which is considered as the source area of the measured EC signal. This area is commonly known as a footprint. In a real-life situation a turbulent flow in the atmosphere is chaotic and the eddies propelling turbulence differ in size and speed. In principle, the EC methodology assumes, that at chosen averaging time interval, the product of vertical wind velocity and the quantity of the substance, heat or momentum carried by the air should be equal to the substance, heat or momentum flux respectively. The vertical flux of a scalar constituent $\left(\mathrm{CO}_{2}\right)$ is calculated as follows:

$$
F=\overline{w^{\prime} c^{\prime}},
$$

where: $w-$ is the vertical wind speed $\left(\mathrm{m} \mathrm{s}^{-1}\right)$ and $c$ - is the quantity of interest ( $\mathrm{mg} \mathrm{m}^{-3}$ ) (gas concentration). The overbar denotes the time averaging, and the prime denotes the fluctuation of the instantaneous value from this average:

$$
w=\bar{w}-w .
$$

The EC technique requires fast response instruments, sampling typically at $10-20 \mathrm{~Hz}$ (Aurela et al., 1998). In recent years the EC technique has been developed the most in comparison to other measuring methods applied for the assessment of mass and energy fluxes (Aubinet et al., 2000).

In order to compare particular $\mathrm{CO}_{2}$ fluxes of different ecosystems from the CarboEurope-IP database the following sites were selected: Sodankylä (Finland), Hyytiälä (Finland), Norunda (Sweden), Tuczno (Poland), Loobos (The Netherlands), Brasschaat (Belgium), Le Bray (France), San Rossore (Italy) (Fig. 1). They are located in both temperate and boreal forests. For these sites the correlation between the average seasonal course of NEP (as the average for the period 2003-2007) and meteorological conditions was examined. Furthermore, a seasonal course of 5-years average values of air temperature and precipitation was presented. Additionally, to compare the NEP fluxes across Europe the average net ecosystem exchange total values for 


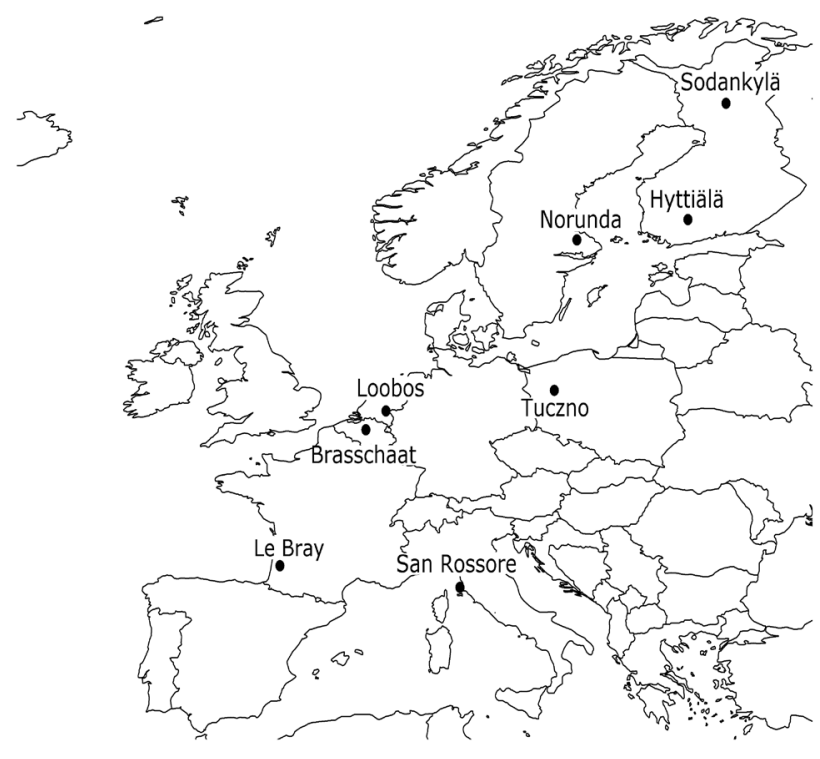

Fig. 1. Location of selected sites from the CarboEurope-IP. each measurement year were calculated. The same applies to the 5-years average (for the years 2008-2012) NEP values which were later compared with the NEP fluxes from the Tuczno forest site. The data from these periods were selected because of their availability at all sites. We also reduced the number of years to five, because it was the longest reference time at the newest site - Tuczno. Our intention was to give the same weight to each site.

Data concerning fluxes and meteorological variables (completed by using the Marginal Distribution Sampling method) were downloaded from the European fluxes database (Level 4 data-http://gaia.agraria.unitus.it/home). Selected sites characteristics are presented in Table 1. The data were collected and processed in accordance with the recommendations of Papale (Papale et al., 2006). Individual data collection methodologies for each site were described in previous studies Carrara et al. (2003), Schelhaas et al. (2004) and Suni et al. (2003).

The analyses presented in this assessment are based on the daily means and sums of data provided by the database. The average values of raw data were computed in Microsoft

T a b l e 1. General description and site characteristics of the selected pine forest stands

\begin{tabular}{|c|c|c|c|c|c|c|c|c|}
\hline Localization & Le Bray ${ }^{1}$ & $\begin{array}{c}\text { San } \\
\text { Rossore }^{2}\end{array}$ & Hyytiälä3 & Sodankylä ${ }^{4}$ & Brasschaat $^{5}$ & Loobos $^{6}$ & Norunda $^{7}$ & Tuczno $^{8}$ \\
\hline Species & \multicolumn{2}{|c|}{ Pinus pinaster } & \multicolumn{6}{|c|}{ Pinus sylvestris } \\
\hline composition (\%) & 100 & 84 & 100 & 100 & 85 & 93.8 & 99 & 99 \\
\hline $\begin{array}{l}\text { Air temperature } \\
\left({ }^{\circ} \mathrm{C}\right) \text { long term }\end{array}$ & 13.5 & 15.1 & 3.8 & -1.0 & 9.8 & 9.8 & 5.5 & 7.8 \\
\hline $\begin{array}{l}\text { Air temperature } \\
\left({ }^{\circ} \mathrm{C}\right) \\
5 \text { years average }\end{array}$ & 13.1 & 15.3 & 4.5 & 0.9 & 11.5 & 10.4 & 6.7 & 9.8 \\
\hline $\begin{array}{l}\text { Precipitation }(\mathrm{mm}) \\
\text { long term }\end{array}$ & 900 & 918 & 709 & 500 & 750 & 786 & 530 & 625 \\
\hline $\begin{array}{l}\text { Precipitation }(\mathrm{mm}) \\
5 \text { years average }\end{array}$ & 926 & 642 & 488 & 346 & 696 & 854 & 560 & 583 \\
\hline $\begin{array}{l}\text { Forest stand age } \\
\text { (years) }\end{array}$ & 42 & 45 & 46 & 65 & 83 & 103 & 114 & 54 \\
\hline LAI & $2.6-3.1$ & 4.0 & 3.0 & 1.2 & 1.3 & $1.9-2.2$ & 5.0 & $1.1-1.2$ \\
\hline Tree height (m) & 17 & 18 & 12 & 13 & 23 & 15 & 25 & 23 \\
\hline $\begin{array}{l}\text { Forest stand } \\
\text { density (trees ha-1) }\end{array}$ & 500 & 567 & 2500 & 2100 & 375 & 360 & 600 & 900 \\
\hline $\begin{array}{l}\text { NEPy } \\
\left(\mathrm{g} \mathrm{C} \mathrm{m}^{-2} \text { year }^{-1}\right)\end{array}$ & 350 & 532 & 228 & -57 & 122 & 450 & 21 & 645 \\
\hline $\begin{array}{l}\text { GEPy } \\
\left(\mathrm{g} \mathrm{C} \mathrm{m}^{-2} \text { year }^{-1}\right)\end{array}$ & 1731 & 1870 & 1013 & 569 & 1178 & 1567 & 1350 & 2071 \\
\hline $\begin{array}{l}\mathrm{R}_{\mathrm{ECO}} \\
\left(\mathrm{g} \mathrm{C} \mathrm{m}^{-2} \text { year }^{-1}\right)\end{array}$ & 1384 & 1338 & 785 & 626 & 1056 & 1117 & 1321 & 1426 \\
\hline Related literature & $\begin{array}{l}\text { (Stella et } \\
\text { al., 2009) }\end{array}$ & $\begin{array}{l}\text { (Chiesi et } \\
\text { al., 2005) }\end{array}$ & $\begin{array}{c}\text { (Suni et } \\
\text { al., 2003) }\end{array}$ & $\begin{array}{l}\text { (Köster et } \\
\text { al., 2013) }\end{array}$ & $\begin{array}{l}\text { (Nagy et } \\
\text { al., 2006) }\end{array}$ & $\begin{array}{l}\text { (Elbers et } \\
\text { al., 2011) }\end{array}$ & $\begin{array}{l}\text { (Lundin et } \\
\text { al., 1999) }\end{array}$ & $\begin{array}{c}\text { (Ziemblińska } \\
\text { et al., 2013) }\end{array}$ \\
\hline
\end{tabular}

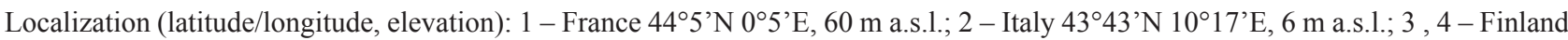
$61^{\circ} 5^{\prime} \mathrm{N} 24^{\circ} 17^{\prime} \mathrm{E}, 170 \mathrm{~m}$ a.s.1.; $67^{\circ} 21^{\prime} \mathrm{N} 26^{\circ} 38^{\prime} \mathrm{E}, 180 \mathrm{~m}$ a.s.1.; 5 - Belgium $51^{\circ} 18^{\prime} \mathrm{N} 4^{\circ} 31^{\prime} \mathrm{E}, 16 \mathrm{~m}$ a.s.1.; 6 - Netherlands $2^{\circ} 10^{\prime} \mathrm{N} 5^{\circ} 44^{\prime} \mathrm{E}$, $25 \mathrm{~m}$ a.s.l.; 7 - Sweden $60^{\circ} 5^{\prime} \mathrm{N} 17^{\circ} 29^{\prime} \mathrm{E}, 45 \mathrm{~m}$ a.s.1.; 8 - Poland $53^{\circ} 11^{\prime} \mathrm{N} 16^{\circ} 05^{\prime} \mathrm{E}, 180 \mathrm{~m}$ a.s.l. 
Excel (2007). Statistical analyses of the annual averages and totals, were performed using dynamic scripts in R statistical software, version 3.1.1, R Core Team (2014). At the outset using last square method, linear models coefficients (slope and intercept), was calculated. For each model, coefficients of determination $\left(\mathrm{R}^{2}\right)$, defined as the square of the Pearson correlation coefficient, was also computed. In order to verify the slope of the lines are not equal 0 , the F-test for each model was performed, and the p-value for the F-test was determined. It was assumed that the limit value for the level of significance for the test-F is 0.05 .

For the GSL designation, the authors divided each site-year into a 10-days periods and the GEP averages values were calculated for these periods. The end of the first 10-days period, in which a GEP flux exceeds an average annual value by $15 \%$, was treated as an indication of the beginning of a growing season. Similarly, the end of a growing season was defined as the end of the first 10-days periods, in which a GEP flux dropped under the average annual value by $15 \%$. A half-hourly averaged data of air temperature were used to calculate the annual average values (for each site), then the average of the selected fiveyears air temperature (tay) was calculated for each site. The annual totals of the net ecosystem exchange (NEPy), precipitation (Py) and photosynthetic photon flux density (PPFDy) were calculated in a similar way. Obtained results were then used to perform a linear relationship between the NEPy and the tay (Fig. 2a), Py (data not shown) and the PPFDy (data not shown), for all selected sites. In addition, linear regressions were made for the NEPy and LAI (data not shown), as well as the NEPy and the latitude (lati) (Fig. 2b), and the NEPy and the GSL relationship (Fig. 2c). Some regression models are not presented here because of their poor performance $\left(\mathrm{R}^{2}<0.2\right)$ and any statistical significance $(\mathrm{p}<0.05)$.

\section{RESULTS AND DISCUSSION}

Estimation of NEPy by a simple model, based on statistically significant correlations with any of easily measureable habitat parameters, was found to be difficult. It comes from the differences of climatic conditions variability (temperature, radiation, humidity) as well as soil properties (soil type, moisture, fertility, etc.) among analyzed sites. It is well known that NEP is a balance value of two fluxes: $\mathrm{GEP}$ and $\mathrm{R}_{\mathrm{ECO}}$. The main weather factor influencing GEP, via an impact on photosynthesis process, is solar radiation, whereas soil properties and air temperature are the drivers of ecosystem respiration. The intensity of $\mathrm{CO}_{2}$ uptake during photosynthesis is also dependent on plant phenology (Wu et al., 2013). However, in this paper we focus on the relationships between easily accessible parameters only derived from the European database and the cumulative NEP values at the annual time scale.
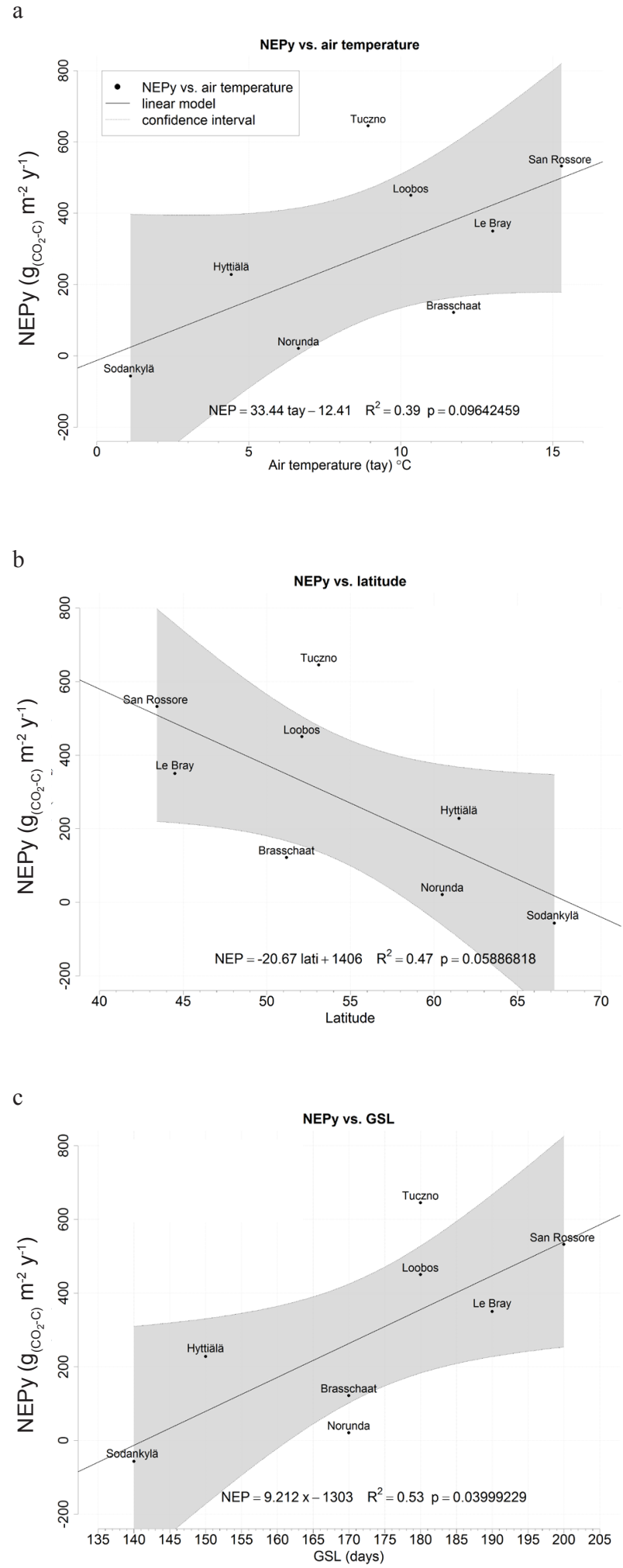

Fig. 2. The relationships between 5-years average annual NEP fluxes (NEPy) and a - air temperature, b - latitude, c - growing season length (GSL), of selected European forest research stations. 
Prior to the analysis described above, special attention was paid to the Sodankylä station (located in the north of Finland in a boreal forest ecosystem) which act as a $\mathrm{CO}_{2}$ source. The observed NEP totals were negative - both in particular years and the 5-years average $\left(-57 \mathrm{~g} \mathrm{CO}_{2}-\mathrm{C} \mathrm{m}^{-2}\right.$ $\left.\mathrm{y}^{-1}\right)$. This relatively long-term tendency at this site was difficult to explain. For some reasons, the annual $\mathrm{R}_{\mathrm{ECO}}$ outweighs the GEP every year in the whole five-years period. It was quite logical in the past, since the $\mathrm{CO}_{2}$ assimilation must have been bigger than the $\mathrm{CO}_{2}$ release, because some organic matter was deposited there. There is some explanation of this phenomenon in the literature (Köster et al., 2013). Sodankylä is situated on a sandy soil with about $0.5 \mathrm{~cm}$ thick layer of humus. Moreover, the region of the site is among the five largest reindeer herding districts of Finland. The number of reindeers has increased three times during the last 50 years. The authors showed, that the total ground vegetation biomass was $62 \%$ higher in the ungrazed area as compared to that in the grazed region. Generally, in high latitudes the less radiation comes in, causing GEP to be low. It reduces also the $\mathrm{R}_{\mathrm{ECO}}$, although respiration process still takes place even if soil temperature comes near to $0^{\circ} \mathrm{C}$ (Juszczak et al., 2012, 2013). For these reasons, the other two Scandinavian sites (Norunda and Hyytiälä) are also characterized by low annual NEP. Besides, the decomposition rate of organic matter is lower in a boreal forest compared to a temperate one, due to lower temperature and (unlike at other sites) a thin organic layer. In such conditions the soil microorganisms are not so active, what cause the decrease in heterotrophic respiration.

The influence of air and soil temperature on the intensity of photosynthesis and respiration, and therefore, also on the NEP fluxes in Finnish boreal forests, was observed especially in early spring and late autumn (Vesala et al., 2010). In these periods, freezing temperatures on the one hand delay the beginning of vegetation season (spring), thus decreasing the intensity of $\mathrm{CO}_{2}$ assimilation, and on the other accelerate the end of tree growth in autumn. The attention should also be directed to the NEP fluxes in very cold periods, when the air temperature drops below $0^{\circ} \mathrm{C}$ (even up to $-15^{\circ} \mathrm{C}$ ). As indicated at the Sodankylä and Norunda sites the net $\mathrm{CO}_{2}$ exchange in winter was close to zero. A similar influence of meteorological conditions on the annual NEP fluxes, as described for a boreal forest, can be found also for temperate forest ecosystems (Poyatos et al., 2007).

In comparison with the sites in the presented analysis the middle-aged Scots Pine forest stand in Poland show some of the highest annual NEP flux values equals to $645 \mathrm{~g}$ $\mathrm{C} \mathrm{m}^{-2}$ year $^{-1}$. We assume, that the Tuczno forest is currently achieving the highest rate of its growth. Moreover, at the majority of the growing season (summer time) the litter layer is probably too dry to be decomposed. Therefore, the respiration intensity might be not as high as in the forests of higher average annual temperatures and annual sum of precipitation in western and southern Europe. This can be one of the cause of the largest annual value of the NEPy.
Our analyses indicate that NEP variation can be exlained by the average air temperature, the latitude and the growing season length differences (Fig. 2). Other parameters, such as precipitation, soil water content, stand density, water table level and photosynthetic photon flux density totals, were excluded from the analysis because they showed very week, non-statistically significant correlation, with the NEPy. In presented studies the annual variability of NEP fluxes in different forest ecosystems across Europe can be explained by the mean annual air temperature, latitude and growing season length (GSL) changes in 39,47 , and $53 \%$, respectively. Nevertheless, only the relationship between NEPy and GSL was statistically significant at chosen 0.05 significance level $(p=0.04)$ (Fig. 2c).

The poor linear regression between the NEPy and the tay (Fig. 2a) can be explained by the fact, that it was probably of curvilinear type. However, with such a small amount of data the application of any non-linear formula seems risky, although in the literature such formulas for at different time scales are known (Falge et al., 2001) phenology patterns, and stress conditions. The comparisons are usually performed on annual sums of FNEE; however, the average data coverage during a year is only $65 \%$. Therefore, robust and consistent gap filling methods are required. We review several methods of gap filling and apply them to data sets available from the EUROFLUX and AmeriFlux databases. The methods are based on mean diurnal variation (MDV. Despite the fact that described regression is not statistically significant, it is worth noting that its tendency seems to be reasonable and the intercept was around -12.41 , which is very close to the expected value of 0 , due to the reduction of biological activity (and $\mathrm{CO}_{2}$ fluxes) in cold conditions. This value can be also an artefact, an effect of using annual mean air temperature versus NEPy, but analysis based on daily data shows that the value of intercept is also near 0 .

The results of the second relationship presented below (NEPy versus latitude) seems to be quite interesting. The course of this simple linear correlation indicates that the NEPy value approaches zero at the latitude of around 68 degree north. This is consistent with reality. In general, as derived from described relationship annual NEPy shows growing tendency with decreasing latitude (Fig. 2b).

The last analyzed linear relationship seems to be the best model for estimating NEPy of the Scots pine in European climatic conditions. Unfortunately, the interpretation of the formula obtained by the regression is not as simple as in the previously discussed cases. It is notice worthy, that when the GSL equals 0 the NEPy reaches up to $-1303 \mathrm{~g}\left(\mathrm{CO}_{2}-\mathrm{C}\right)$ $\mathrm{m}^{-2} \mathrm{y}^{-1}$. The negative value indicates the net emission results from ecosystem respiration only. Since NEP is the balance between the GEP and the $\mathrm{R}_{\mathrm{ECO}}$, the absence of the growing season means that the GEPy is equal to 0 . As a result, our model indicates that when there is no photosynthesis the amount of respired $\mathrm{CO}_{2}$ will be around $1303 \mathrm{~g}\left(\mathrm{CO}_{2}-\mathrm{C}\right)$ $\mathrm{m}^{-2} \mathrm{y}^{-1}$. This is definitely not true, because without growing 
season there would be no plants, and as consequence would be no organic matter in the soil. Thus, both the absorption and respiration would amount to 0 . This tendency is visible in Table 1, the $\mathrm{R}_{\mathrm{ECO}}$ and GEP decreases with the growing season shortening. It is the effect of the low air and soil temperature which is mostly responsible for the reduction of biological activity, and consequently the reduction in both $\mathrm{CO}_{2}$ effluxes - from soil and plants respiration.

Therefore, an extrapolation using the proposed model (despite the significance of the regression) is impossible. On the other hand, the data presented in this work fully covers the entire range of the Scots pine occurrence in Europe, so that there is probably no need for extrapolating the proposed formula.

\section{CONCLUSIONS}

1. The assigned growing season length and the latitude of a particular forest stand in Europe can be the parameters which allow the approximate estimation of the average annual total of the net ecosystem production flux.

2. Presented models are though not perfect, as there are limitations to their use. Their application requires caution, and as it was pointed out, prediction capabilities are limited only to the range of the GSL, which has been presented in the paper.

3 . The models were created involving a relatively small population of data, which limited our ability to put forward other (non linear) formulas. Bigger dataset could presumably significantly improve some relationships performance.

4. Large residuals (for Tuczno, Norunda) in different models can sometimes be an effect of the influence of the factors which could not be determined in this work. Our analysis attempts were limited to those presented above, mainly because of the data availability issue.

\section{REFERENCES}

Aubinet M., Grelle A., Ibrom A., Rannik S., Moncrieff J., Foken T., Kowalski A.S., Martin P.H., Berbigier P., Bernhofer C., Clement R., Elbers J.A., Granier A., Grünwald T., Morgenstern K., Pilegaard K., Rebmann C., Snijders W., Valentini R., and Vesa T., 2000. Estimates of the annual net carbon and water exchange of forests: the EUROFLUX methodology. Adv. Ecol. Res., 30113-175.

Aurela M., Tuovinen J.-P., and Laurila T., 1998. Carbon dioxide exchange in a subarctic peatland ecosystem in northern Europe measured by the eddy covariance technique. J. Geophys. Res., 103 (D10), 11289.

Barr A., Black T.A., and Mccaughey H., (Eds) 2009. Climatic and Phenological Controls of the Carbon and Energy Balances of Three Contrasting Boreal Forest Ecosystems in Western Canada. In: Asko Noormets. Phenology of Ecosystem Processes. New York, NY, Springer New York.

Carrara A., Kowalski A.S., Neirynck J., Janssens I.A., Yuste J.C., and Ceulemans R., 2003. Net ecosystem $\mathrm{CO}_{2}$ exchange of mixed forest in Belgium over 5 years. Agric. For. Meteorol., 119(3-4), 209-227.
Ceulemans R., Kowalski A.S., Berbigier P., Dolman A.J., Grelle A., Janssens I.A., Lindroth A., Moors E., Rannik U., and Vesala T., 2003. Coniferous Forests (Scots and Maritime Pine): Carbon and Water Fluxes, Balances, Ecological and Ecophysiological Determinants. In: Fluxes of Carbon, Water and Energy of European Forests (Ed. R. Valentini). Berlin, Heidelberg, Springer Berlin Heidelberg.

Chapin III F.S., Matson P.A., and Vitousek P., 2011. Principles of Terrestrial Ecosystem Ecology. 2nd edition. Springer New York.

Chen W.J.W., Black T.A., Yang P.C., Barr A.G., Neumann H.H., Nesic Z., Blanken P.D., Novak M.D., Eley J., Ketler R.J., and Cuenca R., 1999. Effects of climatic variability on the annual carbon sequestration by a boreal aspen forest. Glob. Chang. Biol., 5(1), 41-53.

Chiesi M., Maselli F., Bindi M., Fibbi L., Cherubini P., Arlotta E., Tirone G., Matteucci G., and Seufert G., 2005. Modelling carbon budget of Mediterranean forests using ground and remote sensing measurements. Agric. For. Meteorol., 135(1-4), 22-34.

Churkina G., Schimel D., Braswell B.H., and Xiao X., 2005. Spatial analysis of growing season length control over net ecosystem exchange. Glob. Chang. Biol., 11(10), 1777-1787.

Ciais P., Paris J.D., Marland G., Peylin P., Piao S.L., Levin I., Pregger T., Scholz Y., Friedrich R., Rivier L., Houwelling S., and Schulze E.D., 2010. The European carbon balance. Part 1: fossil fuel emissions. Glob. Chang. Biol., 16(5), 1395-1408.

Coursolle C., Margolis H.A., Giasson M.-A., Bernier P.-Y., Amiro B.D., Arain M.A., Barr G., Black T.A., Goulden M.L., McCaughey J.H., Chen J.M., Dunn L., Grant R.F., and Lafleur P.M., 2012. Influence of stand age on the magnitude and seasonality of carbon fluxes in Canadian forests. Agric. For. Meteorol., 165, 136-148.

Dragoni D., Schmid H.P., Wayson C.A., Potter H., Grimmond C.S.B., and Randolph J.C., 2011. Evidence of increased net ecosystem productivity associated with a longer vegetated season in a deciduous forest in south-central Indiana, USA. Glob. Chang. Biol., 17(2), 886-897.

Elbers J.A., Jacobs C.M.J., Kruijt B., Jans W.W.P., and Moors E.J., 2011. Assessing the uncertainty of estimated annual totals of net ecosystem productivity: A practical approach applied to a mid latitude temperate pine forest. Agric. For. Meteorol., 151(12), 1823-1830.

Falge E., Baldocchi D., Olson R., Anthoni P., Aubinet M., Bernhofer C., Burba G., Ceulemans R., Clement R., Dolman H., Granier A., Gross P., Grünwald T., Hollinger D., Jensen N.-O., Katul G., Keronen P., Kowalski A., Lai C.T., Law B.E., Meyers T., Moncrieff J., Moors E., Munger J.W., Pilegaard K., Rannik Ü., Rebmann C., Suyker A., Tenhunen J., Tu K., Verma S., Vesala T., Wilson K., and Wofsy S., 2001. Gap filling strategies for defensible annual sums of net ecosystem exchange. Agric. For. Meteorol., 107(1), 43-69.

Hu J., Moore D.J.P., Burns S.P., and Monson R.K., 2010. Longer growing seasons lead to less carbon sequestration by a subalpine forest. Glob. Chang. Biol., 16(2), 771-783.

Jandl R., Lindner M., Vesterdal L., Bauwens B., Baritz R., Hagedorn F., Johnson D.W., Minkkinen K., and Byrne 
K.A., 2007. How strongly can forest management influence soil carbon sequestration? Geoderma, 137(3-4), 253-268.

Juszczak R., Acosta M., and Olejnik J., 2012. Comparison of daytime and nighttime ecosystem respiration measured by the closed chamber technique on a temperate mire in Poland. Polish J. Environ. Stud., 21(3), 643-658.

Juszczak R., Humphreys E., Acosta M., Michalak-Galczewska M., Kayzer D., and Olejnik J., 2013. Ecosystem respiration in a heterogeneous temperate peatland and its sensitivity to peat temperature and water table depth. Plant Soil, 366(1-2), 505-520.

Keenan T.F., Hollinger D.Y., Bohrer G., Dragoni D., Munger J.W., Schmid H.P., and Richardson A.D., 2014. Brief Communication Arising. Air pollution and forest water use. (Ed. C.D. Holmes). Nature 507, E1-E2 (13 March 2014) doi:10.1038/nature13113

Köster E., Köster K., Aurela M., Laurila T., Berninger F., Lohila A., and Pumpanen J., 2013. Impact of reindeer herding on vegetation biomass and soil carbon content: a case study from Sodankylä, Finland. Boreal Environ. Res., 18 (Sup A) (December), 35-42.

Lal R., 2005. Forest soils and carbon sequestration. For. Ecol. Manage., 220(1-3), 242-258.

Lundin L.-C., Halldin S., Lindroth A., Cienciala E., Grelle A., Hjelm P., Kellner E., Lundberg A., Mölder M., Morén A.-S., Nord T., Seibert J., and Stähli M., 1999. Continuous long-term measurements of soil-plant-atmosphere variables at a forest site. Agric. For. Meteorol., 98-99, 53-73.

Luyssaert S., Ciais P., Piao S.L., Schulze E.-D., Jung M., Zaehle S., Schelhaas M.J., Reichstein M., Churkina G., Papale D., Abril G., Beer C., Grace J., Loustau D., Matteucci G., Magnani F., Nabuurs G.J., Verbeeck H., Sulkava M., Van Der Werf G.R., and Janssens I.A., 2010. The European carbon balance. Part 3: forests. Glob. Chang. Biol., 16(5), 1429-1450.

Luyssaert S., Janssens I., Sulkava M., Papale D., Dolman J., Reichstein M., Hollmén J., Martin J.G., Suni T., Vesala T., Loustau D., Law B.E., and Moors E.J., 2007. Photosynthesis drives anomalies in net carbon-exchange of pine forests at different latitudes. Glob. Chang. Biol., 13(10), 2110-2127.

Nagy M.T., Janssens I.., Curiel Yuste J., Carrara A., and Ceulemans R., 2006. Footprint-adjusted net ecosystem $\mathrm{CO}_{2}$ exchange and carbon balance components of a temperate forest. Agric. For. Meteorol., 139(3-4), 344-360.

Niu S., Luo Y., Fei S., Yuan W., Schimel D., Law B.E., Ammann C., Arain M.A., Arneth A., Aubinet M., Barr A., Beringer J., Bernhofer C., Black T.A., Buchmann N., Cescatti A., Chen J., Davis K.J., Dellwik E., Desai A.R., Etzold S., Francois L., Gianelle D., Gielen B., Goldstein A., Groenendijk M., Gu L., Hanan N., Helfter C., Hirano T., Hollinger D.Y., Jones M.B., Kiely G., Kolb T.E., Kutsch W.L., Lafleur P., Lawrence D.M., Li L., Lindroth A., Litvak M., Loustau D., Lund M., Marek M., Martin T.A., Matteucci G., Migliavacca M., Montagnani L., Moors E., Munger J.W., Noormets A.,
Oechel W., Olejnik J., Kyaw Tha Paw U, Pilegaard K., Rambal S., Raschi A., Scott R.L., Seufert G., Spano D., Stoy P., Sutton M.A., Varlagin A., Vesala T., Weng E., Wohlfahrt G., Yang B., Zhang Z., and Zhou X., 2012. Thermal optimality of net ecosystem exchange of carbon dioxide and underlying mechanisms. New Phytol., 194(3), 775-83.

NOAA, 2014. NOAA In Situ Carbon Dioxide $\left(\mathrm{CO}_{2}\right)$ Measurements. Available at: http//www.esrl.noaa.gov/gmd/obop/ mlo/programs/esrl/co2/co2.html. 2014. U.S. Department of Commerce, National Oceanic and Atmospheric Administration, Earth System Research Laboratory, Global Monitoring Division.

Papale D., Reichstein M., Aubinet M., Canfora E., Bernhofer C., Kutsch W., Longdoz B., Rambal S., Valentini R., Vesala T., and Yakir D., 2006. Towards a standardized processing of Net Ecosystem Exchange measured with eddy covariance technique: algorithms and uncertainty estimation. Biogeosciences, 3(4), 571-583.

Poyatos R., Martínez-Vilalta J., and Čermák J., 2007. Plasticity in hydraulic architecture of Scots pine across Eurasia. Oecologia, 153(2), 245-59.

Schelhaas M.J., Nabuurs G.J., Jans W., Moors E., Sabaté S., and Daamen W.P., 2004. Closing the carbon budget of a Scots pine forest in the Netherlands. Clim. Change, 67 (2-3), 309-328.

Schulze E., Hessenmoeller D., Knohl A., Luyssaert S., Boerner A., and Grace J., 2009. Temperate and boreal old-growth forests: how do their growth dynamics and biodiversity differ from young stands and managed forests? In: Old-Growth Forests. Ecological Studies (Eds C. Wirth, G. Gleixner, M. Heimann). Springer Berlin Heidelberg.

Stella P., Lamaud E., Brunet Y., Bonnefond J., Loustau D., and Irvine M., 2009. Simultaneous measurements of $\mathrm{CO}_{2}$ and water exchanges over three agroecosystems in SouthWest France. Biogeosciences, 6(12), 2957-2971.

Suni T., Rinne J., Reissell A., Altimir N., Keronen P., Rannik Ü., Dal Maso M., Kulmala M., and Vesala T., 2003. Long-term measurements of surface fluxes above a Scots pine forest in Hyytiälä, southern Finland, 1996-2001. Boreal Environ. Res., 8(4), 287-301.

Vesala T., Launiainen S., Kolari P., Pumpanen J., Sevanto S., Hari P., Nikinmaa E., Kaski P., Mannila H., Ukkonen E., Piao S.L., and Ciais P., 2010. Autumn temperature and carbon balance of a boreal Scots pine forest in Southern Finland. Biogeosciences, 7(1), 163-176.

Wu C., Chen J.M., Black T.A., Price D.T., Kurz W.A., Desai A.R., Gonsamo A., Jassal R.S., Gough C.M., Bohrer G., Dragoni D., Herbst M., Gielen B., Berninger F., Vesala T., Mammarella I., Pilegaard K., and Blanken P.D., 2013. Interannual variability of net ecosystem productivity in forests is explained by carbon flux phenology in autumn. Glob. Ecol. Biogeogr., 22(8), 994-1006.

Ziemblińska K., Urbaniak M., Danielewska A., Baran M., Juszczak R., Chojnicki B.H., and Olejnik J., 2013. Seasonal water use efficiency (WUE) index course in pine forest (in Polish). Ann. Environ. Prot., 15(1), 2780-2798. 